\title{
Fakebusters II
}


This page is intentionally left blank 
Series in Popular Science - Vol. 4

\title{
Fakebusters II \\ Scientific Detection of Fakery in Art and Philately
}

\author{
edited by \\ Richard J. Weiss and Duane Chartier
}

Based on the proceedings of the symposium held at PHOTONICS EAST 1999

sponsored by

SPIE, the International Optical Engineering Society, Bellingham, WA 98227-0010, USA

ICAI, the International Center for Art Intelligence, Culver City, CA 90230-5109, USA

FFE, Fakes, Forgeries, and Experts, Castagnola, CH-6976, Switzerland

\section{Noworld Scientific}




\section{Published by}

World Scientific Publishing Co. Pte. Ltd.

5 Toh Tuck Link, Singapore 596224

USA office: 27 Warren Street, Suite 401-402, Hackensack, NJ 07601

UK office: 57 Shelton Street, Covent Garden, London WC2H $9 \mathrm{HE}$

Cover design and illustration: Studio Galleani, Los Angeles, CA Typesetting: One Step Ahead, Brockton, MA

Color layout: Photo Lab, Randolph, MA

\section{FAKEBUSTERS II}

Copyright $\odot 2004$ SPIE and ICAI

All rights reserved.

ISBN 981-256-025-4 (pbk) 
This page is intentionally left blank 


\section{Table of Contents}

1. Preface 1

Richard J. Weiss

Fakebusters

2. R. W. Wood; Fakebuster Extraordinaire 2

Extract from the Biography "Doctor Wood, Modern Wizard of the Laboratory"

William Seabrook

3. Art Fakes and The Statue of Limitations 23

Alan Feld

Law Professor at Boston University

4. Authenticity of Engraved Scrimshaw

Donald Ridley

Assistant Curator, Kendall Whaling Museum

5. Detection of Philatelic Forgeries

Mercer Bristow

American Philatelic Society

Director of the Expertizing Service

6. Insurability of Art 66

Renée Vara,

Chubb Insurance 
7. DNA as a Security Marker

\author{
Chris Outwater \\ DNA Technologies Inc., Los Angeles,CA \\ Rick Tullis \\ DNA Sciences, Carlsbad, CA
}

8. Authentication at a Small Museum

Douglas K. S. Hyland

New Britain Museum of American Art, New Britain, CT

9. Art in Transit

Reprinted with permission from The John Liner Review

Dorit Straus

Assistant Vice President of ACE USA

10. Raman Spectroscopy in the Art World

Ken P. J. Williams

Renishaw PLC, Old Town,

Wotton-under-Edge, Glouchestershire

Lucia Burgio and Robin J. H. Clark

University College London, Christopher Ingold

Laboratories

11. Fakes, Forgeries and Experts (FFE) (Philately)

Paolo Vollmeier

Switzerland, President of the Commission for the Fight Against Forgeries of the F.I.P 
12. Madame Curie (Fiction)

Richard J. Weiss

Fakebusters

13. Non-Destructive Analysis of Artifacts

Manfred Schreiner, Dubravka Jembrih, and

Robert Linke

Institute of Chemistry, Academy of Fine Arts, Vienna, Austria and Institute of Analytical Chemistry, Vienna

University of Technology, Vienna, Austria

Michael Mantler

Institute of Applied and Technical Physics, Vienna

University of Technology, Vienna, Austria

14. International Center for Art Intelligence (ICAI)

Duane Chartier

15. How Appraisers Deal with Authenticity

Edward N. Okil

Executive Director, National Institute of Appraisers

16. Framing and Care of Original Works of Art on Paper

Edward N. Okil

Executive Director, National Institute of Appraisers 
17. Fakery in Graphic Arts

Howard Hansen

Museum of Printing, North Andover, MA

18. Optical Tricks to Foil Counterfeiters

Originally published in "OE REPORTS"

R. Winn Hardin

19. Raman Spectroscopy to Solve Crime

M. Claybourn

Spectroscopy Products Division, Renishaw PLC, Old

Town, Wotton-under Edge, Gloucestershire

M. Ansell

Forensic Document Examiner, Herne Bay, Kent, UK.

20. ICAI, FFE, Roster 10/99

Duane Chartier, ICAI and Paolo Vollmeier, FFE Chairmen

Richard J. Weiss, Fakebusters

Secretary 


\section{1. \\ Preface}

Following the Fakebusters I symposium in January 1998, at San Jose, a second meeting was held in Boston in September 1999. This more eclectic gathering painted a broader swath of the problems in art authentication, now adding philatelic fraud.

Forgers find postage stamps less of a challenge than an oil painting; hence they appear to be more prevalent. There are several well known philatelic expertizing organizations so that Fakebusters is dedicated to helping them with the more sophisticated technologies like Raman and infrared microprobes, both available in portable inexpensive models.

A law professor addressed the statue of limitations, an appraiser elucidated his problems, an insurance expert exposed their handling of questionable art, a director of a small museum narrated his reliance on the 'kindness of strangers' to authenticate etc.

A new organization ICAI, the International Center for Art Intelligence, has been created to help galleries, small museums, auction houses, insurers, and private individuals with their problems. It will also address some aspects of philatelic fakery.

The proliferation of high technology instrumentation can only worry forgers but these scoundrels will continue their antisocial behavior. Alertness must be the watchword. 